upon public subscriptions, the library will be conducted exactly as if it were rate-supported, and the association has good reason to hope that the new venture will be as popular as the first, and that these two libraries will effectively demonstrate the need of free public libraries in this extensive London borough. The library at present contains upwards of $2, \infty 00$ volumes; the reading room is well supplied with current literature, and a portion of the room is screened off for the use of ladies.

MANCHESTER.-Dr. Morehouse, Huddersfield, has offered for acceptance to the Committee of the Home Missionary (Unitarian) College, Manchester, his collection of books dealing with Puritanism, a valuable library, gathered during a long life.

ST: KILDA.-In connection with the marriage of the "Queen of St. Kilda," on the 28th May, Messrs. G. Phillips and Son have sent a large map of the British Isles for the School at St. Kilda, together with four wall maps. In order to reduce the monotony of the St. Kildans, over 300 volumes will also be taken out to form a free library.

THE Library at Chatsworth is being rearranged, and the Duke of Devonshire has promised that any surplus or duplicate works shall be sent to the new Library of Toronto University, to replace those destroyed by fire.

We have received a copy of Bloomsbury and St. Giles's, Past and Present, by Mr. George Clinch, of the British Museum, a member of the Library Association. We hope to notice this handsome volume in our next issue.

\title{
Obituary.
}

Mr. Henry Campkin, F.S.A, an original member of the Library Association, died on April 6, aged seventy-four. He was formerly for many years librarian of the Reform Club, to the duties of which position he devoted himself with great energy, paying special attention to the departments of typographical and historical literature. In 1879 he was seized with illness, and since then his days have been passed in retirement, in the possession of a pension from the club funds. Mr. Campkin was imbued with poetic feeling, and his little volume of "Peter Little ; or the Lucky Sixpence," a verse book for his children, which was originally published in 1851 , passed into a fourth edition in 1861 .

\section{Dractical Xibrariansbip.}

A Practical Librarian. - IN recently noticing what has been done by some of the new school of librarians to attract attention to their libraries and the advantages that readers may derive from them, we have been guilty, unintentionally, of an injustice in ignoring the work of one who has for years, alone, and in the face of many difficulties, and actual rebuffs from those for whose good he has been striving, exercised the calling of librarian in its very highest aspect, viz., that of a guide and teacher of his readers. We refer to Mr. J. De Maine Browne, librarian of the Public Library, Douglas, Isle of Man. For a long time, from the opening of the library, The Isle of Man Times has devoted several columns to Mr. Browne's use, and these he has filled with most interesting talk of the books he loves so well and which he evidently longs to see loved by others. Mr. Browne really seems to read his books, and to know something more of them than is, we regret to say, the rule with 
many practical librarians. His plan is a very simple one. On their arrival he publishes a list of the new books added to the library, with notes and comments on the more important of them, and from time to time gives most tempting extracts and notices of some of his older possessions. We know that the result of all this patient work has proved to be of the highest practical value, and has caused Mr. Browne to be surrounded with a circle of true book lovers, who, guided by him, are enriching their minds with the best literature of the day. We wish we could reprint some of his notes, but our limits forbid this, though we hope to arrange shortly to have some reprints, and shall circulate them with The Library as a supplement. We regret to say that some few months ago $\mathrm{Mr}$. Browne's health broke down through over-work and he has been compelled to rest for a time. In his enforced retirement it must have been gratifying to him to receive a complimentary address, signed by some of his most influential readers, in which they express their deep regret and sincere sympathy with him in his illness, and blame the Free Library Committce for their neglect of the ventilation of the reading room to which is ascribed very largely Mr. Browne's breakdown. We sincerely hope he will soon be restored to perfect health and may long continue his career as one of the best examples of a librarian who reads not for himself alone.

Sratistics of Consulting Books.-The sarcastic hint about increasing the issues, given in Jottings, suggests another way of legitimate increase of which I have taken advantage for some years past. In many reference libraries there are placed, for handy reference, a number of what may be termed "consulting books," such as dictionaries, concordances, almanacks, calendars, and the like ; and as credit is not usually taken for the issue of these works, the full use of the reference library is not set forth in the library statistics in such cases. In our little Reference Library at Aston, we have about thirty volumes in our consulting case, and on the top edge of each volume is laid a small, narrow ticket, on which is printed :-"When taking this volume from the shelf, please drop this ticket into the bor;" and in front of the case is placed a small locked box, with a slit in the lid, on which is written :- "Please drop the ticket into this box:" The assistants are instructed to place another ticket on the top of any book from which the former onc has been taken, after the book has been used; and when making up statistics the next morning, the tickets in the box from the former day are counted, and classed as issues of "consulting books." Out of a total of 14,000 reference issues last year, about 2,000 were recorded in this mamer.

R. K. D.

Practical LinRarianship SUPpLemints.-Some of the best work, worthy of notice, under this heading, is best illustrated by the printed matter prepared for the special work of libraries, but the limits of our space make it impossible for us to print such things fully, and unless printed fully they are of little use. For example, it would have been difficult within any reasonable limits to explain Mr. May's circular in such a way as to enable others to copy it, and we therefore resorted to the plan of sending a copy of the circular with each number of The Librury. We believe the extension of this practice would be acceptable, and we shall thercfore be glad to receive from librarians and others anything in the shape of printed matter that illustrates the work of the libraries in which they are interested; and if these are approved of, we shall ask them to supply us with a sufficient number to be issued as a supplement to The Library. We sliould also be glad to circulate in this way copies of plans, elevations of libraries, illustrations of new appliances, such as indicators, \&c. 